\title{
An Analysis of Inequality in Food Consumption Expenditure of Uttar Pradesh, India
}

\author{
Rooba Hasan ${ }^{1 *}$ and D.N. Khan ${ }^{2}$ \\ ${ }^{1}$ Department of Agricultural Economics, Institute of Agricultural Sciences, \\ BHU, Varanasi-221005, India \\ ${ }^{2}$ Industrial Finance Branch, SBI, Pune, India \\ *Corresponding author
}

\section{Keywords \\ Food Consumption, Expenditure, Uttar Pradesh, Income, Inequality \\ Article Info \\ Accepted: \\ 20 May 2019 \\ Available Online: \\ 10 June 2019}

\section{A B S T R A C T}

Uttar Pradesh is one of the fastest developing states of India. Income of the household is one of the important factors affecting consumption of both the food and non-food products. The gap between the rich and the poor in terms of wealth and incomes is huge. Inequality is also very wide in consumption of luxury goods as well as food commodities in Uttar Pradesh. Food Consumption is an important activity performed by the household sectors. Analysis of inequality in food consumption is one of the major successes of economics as it is essential for a wide range of development policies like sectoral food subsidy, policies related to food production, distribution and macroeconomic policy analysis. This paper revealed striking difference in food consumption pattern of households across income groups and rural and urban sectors in Uttar Pradesh. Analysis of food consumption, using consumption expenditure survey conducted by NSSO, revealed a structural shift towards high value agricultural commodities like milk, fruits, vegetables and non-vegetarian products in the state. High disparity among income groups and ruralurban disparities in Monthly per capita expenditure were observed. The analysis showed that while necessities represent a majority of the consumption basket for very poor and poor income classes, consumption of rich classes was influenced towards milk and fruits. Rich households were found to spend more on non-food items and poor households spend more on food items. This effect was more pronounced for rural area as compared to urban area. Thus key findings were conformity with Engel's law. The structural shift and diversification of food basket has definite implications on livelihood security and welfare of the households in state Uttar Pradesh.

\section{Introduction}

The consumption pattern in India underwent a sweeping structural change and now it tends towards assuming a new mobility. The economy witnessed structural changes in the consumption basket of rural and urban sectors and across income groups over the last three decades. Study of consumption patterns is essential as the consumption pattern contains a wealth of useful information regarding food security-related policy issues in the agricultural sector, economic welfare and living standards. 
Sustained economic growth, increasing population and changing lifestyles are causing significant changes in Indian food basket, away from staple food grains towards highvalue food products (Kumar et al., 2007; Mittal, 2007). Although per capita consumption of food grains has declined, their total consumption has increased due to increasing population. Some of decline in per capita consumption indicates an increase in the consumer's welfare (Rao, 2000). Radhakrishna (2005) suggested that substantial expansion of the incomes of the poor is essential for tackling the chronic food insecurity problem.

Uttar Pradesh is world's largest sub-national entity as well as the most populous state in the country accounting for 16.4 per cent of the country's population. It is also the fourth largest state in geographical area covering 9.0 per cent of the country's geographical area. Debates on the issue of food security in terms of the state's self-sufficiency in production, future demand for cereals and other food items as well as the ability of households to meet their calorie requirements are of important policy relevance. The present study diagnoses the income class wise changing food consumption pattern for both the rural and urban sectors in Uttar Pradesh.

\section{Materials and Methods}

The food consumption pattern of was analyzed among income groups using household level consumption data from consumption expenditure survey conducted by National Sample Survey Organization (NSSO). To study the consumption pattern data was taken from rounds number 66 pertaining to the period of 2009-10. For analyzing consumption across different income groups in Uttar Pradesh households were divided into four expenditure groups based on quartile classification. Quartile values were estimated for both rural and urban region as well as Uttar Pradesh. Estimated values of monthly per capita consumption expenditure (MPCE) which are taken as a proxy of income for each sector as well as Uttar Pradesh, given in Appendix 1. The consumption pattern of food commodities was examined for each economic group. The terms consumption expenditure (MPCE) and income will be used synonymously hereafter. Broadly, to study consumption pattern of food commodities, per capita consumption and budget shares of food groups were estimated as follows:

\section{Per capita consumption and budget share}

Monthly per capita consumption for food groups was estimated using following formula:

$$
M P C=\frac{\sum_{i=1}^{n} C_{i}}{\sum_{i=1}^{n} f_{i}}
$$

where,

MPC=monthly per capita consumption $(\mathrm{kg}) /$ expenditure $(\mathrm{Rs}), \quad \mathrm{C}_{\mathrm{i}}=$ monthly consumption/expenditure on food item by $i^{\text {th }}$ household, $\mathrm{n}=$ number of sample household, and $f_{i}=$ family size of $i^{\text {th }}$ sample household.

The share of food groups in total consumption expenditure was measured using following formula:

$W_{g}^{t}=\frac{M P C_{E g}^{t}}{\sum_{g=1}^{m} M P C_{E g}^{t}} \times 100$

Where,

$W_{g}^{t}=$ share of $\mathrm{g}^{\text {th }}$ food group in total food consumption expenditure in $\mathrm{t}^{\text {th }}$ period, $M P C_{E g}^{t}=$ monthly per capita consumption 
expenditure on $\mathrm{g}^{\text {th }}$ food group in $\mathrm{t}^{\text {th }}$ period, and $\mathrm{g}=$ number of food groups $(\mathrm{g}=1,2 \ldots \mathrm{m})$ in food basket.

Per capita consumption and budget shares were estimated for each income group separately to assess the spatial changes in consumption pattern. Per cent change in per capita consumption; budget share over the period under consideration were finally tabulated to interpret results.

\section{Results and Discussion}

Income of the household which is one of the important factors affecting consumption of both the food and non-food products was observed to vary across rural and urban sectors depending upon varying employment opportunities. Because of the significant changes in the rate of income growth by income class over the last few decades, the consumption patterns of different income classes may also have changed.

\section{Income and sector wise consumption expenditure in Uttar Pradesh}

To examine income wise consumption pattern of food products, MPCE and food expenditure was estimated separately for rural and urban sectors. Estimated MPCE and food expenditure at 2008 prices showed greater variability across sectors and income classes with urban sector having about 65 per cent higher income than rural sector and total MPCE was found to be 937 in Uttar Pradesh, for very poor urban sector was having 15 per cent higher income than rural sector, 27.43 per cent more for poor, 49.67 per cent for middle and 86.34 per cent more for rich. A similar pattern was found for food expenditure. Further, very poor households were found to be spending about 61 to 63 per cent of income on food as compare to rich who spent about 32 to 41 per cent with rural households spending greater proportion of MPCE on food than urban households (Table $1)$. Thus, rich households spend more on nonfood items and poor households spend more on food items. This effect was more pronounced for rural area as compared to urban area. This validated Engel's law which states that as income increases, proportion of total expenditure on non-food items increases and expenditure on food items decreases though actual expenditure may increase.

\section{Income wise consumption pattern in Uttar Pradesh during 2009-10}

Income wise examination of the consumption pattern revealed that with the increase in income, per capita consumption of total food increases, but its share in total consumption expenditure decreases in both the rural and urban areas. The share of food expenditure in total consumption expenditure for very poor households was 63.21 and 61.16 per cent in rural and urban areas, respectively. However, rich allocated 41.15 and 33.07 per cent of the total consumption expenditure to food in rural and urban areas, respectively in 2009-10. Thus, rural households, whose income is lower than their urban counterparts, allocated higher proportion of consumption expenditure to food as compared to urban households, in general. The poor households particularly allocated a relatively higher proportion to food than the rich households in both rural and urban areas (Table 2).

Further, within the food basket, per capita consumption of all the food groups increased with the increase in income level but their share in total food consumption expenditure showed mixed trend depending upon the food group (Table 3 ). In case of cereals, pulses, edible oils and vegetables expenditure share reduced, while for milk, non-vegetarian products and fruits increasing trend in expenditure share was observed with the 
increase in income (Table 2 and 3). Interestingly, share of cereals, edible oils and vegetables declined with the increase in income. However, analysis of the cross section data showed that per capita consumption of cereals, edible oils and vegetables had an increasing trend with the rise in income in both rural and urban areas. Share of pulse consumption showed a mixed trend with the rise in income in rural areas while decreasing share in consumption of pulses with the increase in income was observed in urban area. Since per capita consumption of cereals, edible oils and vegetables increases as income rises and there is, in general, a declining trend in share in of these commodities among different classes (Table 2 and 3 ).

In fact, declining per capita consumption of cereals over the years was due to a change in the tastes and preferences of consumers away from food grains towards HVACs. Further, in rural sector, cereals alone accounted for about 39 per cent of total food expenditure of very poor households as against about 24 per cent in case of rich households. Thus, cereals constituted a major share in total food expenditure for all income groups (29.71 per cent), but for low income households the share was significantly higher than for the high income groups. In urban sector, the same pattern was observed, but the share of cereals was less than that of rural sector.

In case of milk, monthly per capita consumption (MPC) was only $2.08 \mathrm{~kg}$ for very poor households with about 11.58 per cent share in food expenditure as against 2.26 $\mathrm{kg}$ MPC for rich households with the share of 24.45 per cent in total food expenditure in rural sector. In case of urban sector, the same pattern was observed but with comparatively higher share in food expenditure than rural sector. Non-vegetarian products and fruits followed similar consumption pattern. Thus, consumption of HVACs such as milk, fruits and non-vegetarian products was significantly biased towards rich strata of households. As well as increasing diversification of food basket and high demand of HVACs is expected in future.

Table.1 Income and sector wise household expenditure in Uttar Pradesh in 2009-10 (in rupees)

\begin{tabular}{|c|c|c|c|c|c|c|c|c|}
\hline \multirow{2}{*}{$\begin{array}{l}\text { Income } \\
\text { Groups }\end{array}$} & \multicolumn{3}{|c|}{ MPCE } & \multicolumn{3}{|c|}{ Food Expenditure } & \multicolumn{2}{|c|}{$\operatorname{RUD}(\%) *$} \\
\hline & Rural & Urban & Total & Rural & Urban & Total & MPCE & Food expenditure \\
\hline V. Poor & 478 & 549 & 493 & $\begin{array}{c}302 \\
(63.21)\end{array}$ & $\begin{array}{c}336 \\
(61.16)\end{array}$ & $\begin{array}{c}309 \\
(62.68)\end{array}$ & 14.85 & 11.26 \\
\hline Poor & 678 & 864 & 716 & $\begin{array}{c}403 \\
(59.49)\end{array}$ & $\begin{array}{c}466 \\
(54.00)\end{array}$ & $\begin{array}{c}420 \\
(58.61)\end{array}$ & 27.43 & 15.63 \\
\hline Middle & 904 & 1353 & 1010 & $\begin{array}{c}495 \\
(54.81)\end{array}$ & $\begin{array}{c}626 \\
(46.23)\end{array}$ & $\begin{array}{c}530 \\
(52.50)\end{array}$ & 49.67 & 26.46 \\
\hline Rich & 1654 & 3082 & 2129 & $\begin{array}{c}681 \\
(41.15)\end{array}$ & $\begin{array}{c}988 \\
(32.07)\end{array}$ & $\begin{array}{c}784 \\
(36.82)\end{array}$ & 86.34 & 45.08 \\
\hline Total & 829 & 1365 & 937 & $\begin{array}{c}438 \\
(52.82)\end{array}$ & $\begin{array}{c}582 \\
(42.65)\end{array}$ & $\begin{array}{c}467 \\
(49.84)\end{array}$ & 64.72 & 33.00 \\
\hline
\end{tabular}

*RUD (\%): Rural-urban difference $\{($ Urban-rural $) /$ rural*100 $\}$

Figures within parentheses are share of food expenditure in total consumption expenditure 
Table.2 Income wise share of food commodities in total food expenditure in Uttar Pradesh in 2009-10 (per cent)

\begin{tabular}{|c|c|c|c|c|c|c|c|c|}
\hline Income & Cereal & Pulses & Milk & Edible Oils & Non-veg & Vegetables & Fruits & Food* \\
\hline \multicolumn{9}{|l|}{ Rural } \\
\hline V. poor & 38.99 & 8.35 & 11.58 & 8.18 & 2.98 & 14.15 & 0.91 & 63.21 \\
\hline Poor & 33.73 & 8.12 & 16.74 & 7.75 & 3.42 & 13.02 & 1.30 & 59.49 \\
\hline Middle & 29.02 & 8.43 & 21.03 & 7.33 & 3.39 & 12.87 & 1.62 & 54.81 \\
\hline Rich & 24.42 & 8.48 & 24.45 & 6.62 & 4.07 & 11.43 & 2.57 & 41.15 \\
\hline Total & 31.29 & 8.34 & 18.68 & 7.44 & 3.49 & 12.81 & 1.63 & 52.82 \\
\hline \multicolumn{9}{|l|}{ Urban } \\
\hline V. poor & 37.01 & 8.18 & 13.49 & 7.63 & 4.52 & 13.20 & 0.99 & 61.16 \\
\hline Poor & 29.42 & 7.90 & 19.10 & 7.43 & 4.39 & 12.82 & 1.93 & 54.00 \\
\hline Middle & 24.51 & 7.55 & 24.47 & 6.73 & 2.73 & 12.61 & 3.03 & 46.23 \\
\hline Rich & 17.47 & 6.62 & 29.16 & 5.61 & 2.42 & 11.70 & 5.12 & 32.07 \\
\hline Total & 24.99 & 7.40 & 23.31 & 6.63 & 3.24 & 12.43 & 3.21 & 42.65 \\
\hline \multicolumn{9}{|l|}{ Total } \\
\hline V. poor & 38.75 & 8.36 & 11.92 & 8.12 & 3.06 & 14.02 & 0.90 & 62.68 \\
\hline Poor & 32.41 & 8.10 & 17.58 & 7.68 & 3.73 & 13.00 & 1.39 & 58.61 \\
\hline Middle & 28.17 & 8.60 & 21.60 & 7.07 & 3.22 & 12.54 & 1.95 & 52.50 \\
\hline Rich & 21.33 & 7.45 & 26.69 & 6.26 & 3.63 & 11.57 & 3.59 & 36.82 \\
\hline Total & 29.71 & 8.10 & 19.84 & 7.24 & 3.43 & 12.72 & 2.02 & 49.84 \\
\hline
\end{tabular}

* Share of food expenditure in total consumption expenditure (MPCE)

Table.3 Income wise consumption of different commodities in Uttar Pradesh in 2009-10

(Kg/person/month)

\begin{tabular}{|c|c|c|c|c|c|c|c|c|}
\hline Income & Cereal & Pulses & Milk & Edible Oils & Non-veg & Vegetables & Fruits & Food* \\
\hline V. poor & 11.01 & 0.64 & 2.08 & 0.39 & 0.09 & 4.23 & 0.12 & 19.27 \\
\hline Poor & 11.89 & 0.72 & 3.96 & 0.50 & 0.13 & 5.09 & 0.21 & 23.43 \\
\hline Middle & 12.22 & 0.84 & 6.05 & 0.59 & 0.15 & 5.88 & 0.27 & 27.14 \\
\hline Rich & 13.41 & 1.08 & 9.17 & 0.75 & 0.26 & 6.73 & 0.44 & 33.38 \\
\hline Total & 11.94 & 0.78 & 4.69 & 0.53 & 0.14 & 5.26 & 0.23 & 24.58 \\
\hline V. poor & 10.03 & 0.58 & 2.26 & 0.41 & 0.16 & 3.88 & 0.12 & 18.19 \\
\hline Poor & 10.12 & 0.67 & 4.14 & 0.57 & 0.20 & 4.94 & 0.29 & 22.02 \\
\hline Middle & 10.25 & 0.80 & 6.61 & 0.68 & 0.13 & 6.00 & 0.44 & 26.31 \\
\hline Rich & 10.10 & 1.06 & 10.95 & 0.86 & 0.16 & 7.71 & 0.94 & 35.07 \\
\hline Total & 10.13 & 0.76 & 5.72 & 0.62 & 0.16 & 5.52 & 0.42 & 24.86 \\
\hline V noor & 1103 & 064 & 216 & 040 & 000 & 422 & 012 & 1037 \\
\hline Poor & 11.59 & 0.72 & 4.22 & 0.52 & 0.15 & 5.15 & 0.22 & 23.54 \\
\hline Middle & 12.08 & 0.87 & 6.27 & 0.61 & 0.15 & 5.89 & 0.32 & 27.43 \\
\hline Rich & 11.96 & 1.03 & 9.77 & 0.80 & 0.24 & 7.03 & 0.58 & 33.42 \\
\hline Total & 11.72 & 0.79 & 5.76 & 0.55 & 0.38 & 5.38 & 0.40 & 24.69 \\
\hline
\end{tabular}

* Share of food expenditure in total consumption expenditure (MPCE) 
Appendix1. Estimated quartile values of MPCE (in rupees)

\begin{tabular}{|c|c|c|c|}
\hline Quartiles & Rural & Urban & Total \\
\hline Quartile 1 (Q1) & 591 & 696 & 615 \\
\hline Quartile 2 (median) & 778 & 1056 & 841 \\
\hline Quartile 3 (Q3) & 1070 & 1772 & 1250 \\
\hline
\end{tabular}

\section{Policy options}

Large variation in food intake among income classes demands policy for ensuring nutritional security in favour of lower income class in the state. Differences in food consumption pattern emphasize policy interventions for pricing and other marketing strategies for income classes and across rural and urban sectors separately to ensure proper dietary intake.

\section{References}

Consumer Expenditure Survey, $43^{\text {rd }}$ and $66^{\text {th }}$ round, NSSO, Ministry of Statistics and Programme Implementation, GOI, New Delhi.

Hasan, Rooba and Singh H.P (2017) Changing Consumption Pattern of Agricultural Commodities in Uttar Pradesh: An Inter Regional Analysis. Indian Journal of Agricultural Economics, 72(3): 326-334.

Kumar, Praduman and Kumar, Pramod (2003), Demand supply and trade perspective of vegetables and fruits in
India. Indian Journal of Agricultural Marketing, 17(3):121-130.

Kumar, Praduman and Mathur, V.C. (1996). Structural Changes in the Demand for Food in India, Indian Journal of Agricultural Economics, 51: 664-73.

Musebe, R.O. and Kumar, P. (2002), "Dietary pattern and nutritional status of rural households in Maharashtra". Agricultural Economics Research Review. 15(2): 111-122.

Radhakrishna, R and Ravi, C. (1992), Effect of Growth, Relative Price and Preferences of Food and Nutrition, The Indian Economics Review, Special Number in memory of Sukhamoy Chakravarty, 27: 30-41.

Radhakrishna, R (2005), "Food and nutrition security of the poor", Economic and Political Weekly, 60 (18): 1817-1821.

Rao, C.H.H. (2000), Declining Demand for Food grains in Rural India: Causes and Implications, Economic and Political Weekly, January 22, Pp-201206.

\section{How to cite this article:}

Rooba Hasan and Khan, D.N. 2019. An Analysis of Inequality in Food Consumption Expenditure of Uttar Pradesh. Int.J.Curr.Microbiol.App.Sci. 8(06): 2603-2608. doi: https://doi.org/10.20546/ijcmas.2019.806.312 